\title{
Temperature effect on the immune defense functions of Arctic charr Salvelinus alpinus
}

\author{
P. Pylkkö ${ }^{1, *}$, T. Lyytikäinen ${ }^{2}$, O. Ritola ${ }^{3}$, S. Pelkonen ${ }^{4}$, E. T. Valtonen ${ }^{5}$ \\ ${ }^{1}$ Finnish Game and Fisheries Research Institute, Laukaa Fisheries Research and Aquaculture, Vilppulantie 415, \\ 41360 Valkola, Finland \\ ${ }^{2}$ National Veterinary and Food Research Institute, PO Box 45, 00581 Helsinki, Finland \\ ${ }^{3}$ Finnish Game and Fisheries Research Institute, Tervo Fisheries Research and Aquaculture, Huuhtajantie 160, \\ 72210 Tervo, Finland
}

${ }^{4}$ Finnish National Veterinary and Food Research Institute, Kuopio Regional Laboratory, PO Box 92, 70210 Kuopio, Finland

${ }^{5}$ University of Jyväskylä, Department of Biological and Environmental Sciences, PO Box 35, 40351 Jyväskylä, Finland

\begin{abstract}
The Arctic charr Salvelinus alpinus is an endangered fish species in Finland, and thus farming is carried out mainly for stocking purposes. Farmed charr are susceptible to infection with atypical Aeromonas salmonicida (aAS). Losses of valuable brood stock will severely reduce the genetic diversity of stocked charr. No commercial vaccines are available to prevent aAS infection, and vaccines against furunculosis (caused by typical $A$. salmonicida, tAS) do not protect the charr against aAS infection. The effects of a metabolizable oil-adjuvanted, bivalent vaccine (containing killed aAS and A. salmonicida salmonicida bacteria) on the immune system of 1 yr old hatcheryreared charr originating from Lake Inari in Northern Finland were examined. Fish vaccination in Finland generally takes place either from October to November or from February to April, when the water temperature is low $\left(1\right.$ to $\left.3^{\circ} \mathrm{C}\right)$. The water temperature starts to increase in mid-May. Therefore, we also investigated whether post-vaccination (p.v.) temperature had an influence on the immune system of this cold-water fish species. The fish were immunized intraperitoneally at $2.9^{\circ} \mathrm{C}$ at the end of April. After $52 \mathrm{~d}$, during which the water temperature increased from 2.9 to $10.0^{\circ} \mathrm{C}$, the charr were exposed to 1 of 3 test temperatures: $10.3,14.1$ or $18.1^{\circ} \mathrm{C}$. Prior to vaccination, and 49,75 and $103 \mathrm{~d}$ p.v., several immune parameters were measured in both unvaccinated and vaccinated charr. Vaccination induced a significant anti-aAS-specific antibody response, and increased plasma lysozyme activity at all p.v. temperatures. The haemolytic activity of the complement system was unaffected either by vaccination or p.v. temperatures. There was a slight positive correlation between p.v. temperature and lysozyme activity of the charr. The significant increase in lysozyme activity took place in vaccinated charr in the first $49 \mathrm{~d}$ p.v. as water temperatures increased from 2.9 to $10^{\circ} \mathrm{C}$. Furthermore, the highest activity of lysozyme in the plasma was observed $49 \mathrm{~d}$ p.v. Our results indicate that a rise in water temperature above $10^{\circ} \mathrm{C}$ does not significantly enhance the vaccination response of charr. This could be one reason why farmed Arctic charr, which are well adapted to a cold climate, are highly susceptible to aAS infection in the summer.
\end{abstract}

KEY WORDS: Arctic charr $\cdot$ Salvelinus alpinus $\cdot$ Temperature $\cdot$ Immune defense functions $\cdot$ Vaccination Resale or republication not permitted without written consent of the publisher

\section{INTRODUCTION}

The Arctic charr Salvelinus alpinus is classified either as a critically endangered (Lake Saimaa area in south-

${ }^{*}$ Present address: Agrifood Research Finland, Fur Animals, Turkistie 8, 69100 Kannus, Finland. E-mail: paivi.pylkko@mtt.fi ern Finland) or threatened (in northern Finland) fish species in Finland. Spawning of charr in nature does not maintain the natural stocks, which are either dependent on or are supported by stocking. Infection with atypical Aeromonas salmonicida (aAS) is the most serious health problem and the greatest cause of losses among farmed charr. Antimicrobial medication is inef- 
fective and there is no commercially available vaccine against aAS. Mortality amongst farmed charr during outbreaks has exceeded $60 \%$ (Pylkkö unpubl. obs.). Losses to farmed charr brood-stocks severely reduce the genetic background of charr available for stocking management.

Mortality due to aAS infection in other salmonids in Finnish fish farms is related to environmental factors such as season, water quality and water temperature (Rintamäki-Kinnunen 1997). Disease outbreaks are reported to occur at water temperatures above $15^{\circ} \mathrm{C}$ (Rintamäki \& Valtonen 1991). In brackish water cultures of the Atlantic salmon Salmo salar in Iceland, aAS outbreaks take place at water temperatures around $8^{\circ} \mathrm{C}$ (Gudmundsðottir 1997).

Among salmonid fishes the Arctic charr is well adapted to cold waters (Johnson 1980). The optimum temperature for growth of farmed charr is from 13 to $14^{\circ} \mathrm{C}$ (Swift 1964, Jobling et al. 1993, Lyytikäinen 1998). Little is known about the immune responses of charr and the effect of temperature on its immune system; also unknown is how the immune system of charr reacts to increasing temperatures after vaccination.

Antibody responses after active immunization have been studied in Atlantic salmon Salmo salar, brown trout Salmo trutta, and various Oncorhynchus species (Thuvander et al. 1987, Gudmundsðottir \& Magnaðottir 1997). Humoral antibodies and neutralization of bacterial toxins are important protective mechanisms in fishes (Gudmundsðottir \& Magnaðottir 1997). The total protein concentration in fish plasma has been reported to increase together with the total immunoglobulin level during Aeromonas salmonicida infection (Magnaðottir \& Gudmundsðottir 1992, Møyner 1993, Magnaðottir et al. 1995).

Pathogens usually have their virulence components located on their surface and in the cell wall. Protection by the host is based on destruction of such components. Lysozyme in vertebrates is one of the enzymes in the first-line defense against invading pathogens (see e.g. Roitt 1994, Janeway et al. 1999). The defense response is directed against the peptidoglycan layer, especially in the cell wall of Gram-positive bacteria, which is thought to be weakened by the alternative pathway of the complement system before enzymatic (lysozyme) attack (see e.g. Janeway et al. 1999). Activation of the complement system, the classical pathway, is based on specific recognition of an invading pathogen while activation of the alternative pathway needs no specific recognition (see e.g. Roitt 1994, Janeway et al. 1999).

The variety of virulence factors and mechanisms of aAS and typical Aeromonas salmonicida (tAS) bacteria indicates that they possess many different means to evade the immune system of fish (Garrote et al. 1992, Merino et al. 1994). A protein of aAS (AsaP1) was found on the one hand to be very toxic to Atlantic salmon and, on the other hand, to be highly immunogenic when used in an autogenous aAS vaccine (Gudmundsðottir et al. 1990, Gudmundsðottir \& Magnaðottir 1997). Virulence components such as capsule production, A-layer protein, lipopolysaccharides, and extracellular products have been reported in aAS and ASS (Gudmundsðottir et al. 1990, Garrote et al. 1992, Merino et al. 1994), although their immunogenicity varies (Gudmundsðottir \& Magnaðottir 1997, O'Dowd et al. 1999).

Vaccination against furunculosis and vibriosis (Vibrio anguillarum) is a well-established practice in fish farming, and has also been successful in protecting brown trout Salmo trutta m. lacustris, Atlantic salmon, and rainbow trout Oncorhynchus mykiss (Thuvander et al. 1987, 1993, Midtlyng et al. 1996). Arctic charr vaccinated with commercial, monovalent or multivalent furunculosis vaccines shave, nevertheless, been diagnosed as having died due to aAS infection (Pylkkö unpubl. data). Fish vaccinations in Finland generally take place either from October to November and/or from February to April when the water temperature ranges from 1 to $3^{\circ} \mathrm{C}$. The water temperature starts to increase in mid-May.

This study examined how a vaccine containing both tAS and aAS bacteria as antigens activate the specific and non-specific immune functions in Arctic charr. The effect of temperature on the immune parameters of charr was experimentally studied at 3 temperatures 10.3, 14.1 and $18.1^{\circ} \mathrm{C}$, which included their optimum growth temperatures and also represented temperatures that are easily reached on Finnish charr farms in summer.

\section{MATERIALS AND METHODS}

Experimental design (Fig. 1). A group of Arctic charr Salvelinus alpinus (average weight $=25.2 \mathrm{~g}, \mathrm{SD}=7.6 \mathrm{~g}$ ) was vaccinated intraperitoneally (i.p.) at a water temperature of $2.9^{\circ} \mathrm{C}$ with a metabolizable oil-adjuvanted, bivalent vaccine $\left(0.2 \mathrm{ml}\right.$ fish $\left.^{-1}\right)$ containing formalin

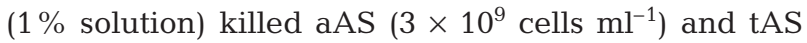
$\left(6 \times 10^{9}\right.$ cells $\left.\mathrm{ml}^{-1}\right)$ bacteria prepared for the study by Alpharma AS, Norway. A group of unvaccinated fish served as controls; these were marked by clipping their adipose fin. The control charr were not injected i.p. with saline because of the results of previous unpublished findings: saline injection induced more serious adhesions in the body cavity of charr than injection with a commercial oil-based vaccine (Pylkkö unpubl. obs). Charr were held in $4 \mathrm{~m}^{2}$ tanks at ambient water temperature and received a low ration of feed $\left(<0.5 \%\right.$ body wt $\left.\mathrm{d}^{-1}\right)$. 
For individual growth measurements, the charr were individually marked i.p. $25 \mathrm{~d}$ post-vaccination (p.v.) with passive integrated transponder (PIT) tags under tricaine sulphonate (MS-222, $0.15 \mathrm{~g} \mathrm{l}^{-1}$ ) anaesthetic (Pylkkö et al. 2000). The inflowing water came from an oligotprohic lake upstream of the station. The water temperature was $6^{\circ} \mathrm{C}$ at the time of tagging. Fish were then held in two $4 \mathrm{~m}^{2}$ flow-through tanks for $7 \mathrm{~d}$ while the water temperature increased naturally to $10^{\circ} \mathrm{C}$, and they were fed as before (Fig. 1). The fish were divided randomly into 9 fibreglass tanks (250 l) 32 d p.v. (72 vaccinated and 31 control fish per tank) and the water temperature was kept at $10^{\circ} \mathrm{C}$ for $20 \mathrm{~d}$. Fish were fed to excess by belt-feeders $(8 \mathrm{~h}$ per day, from 04:00 to $12: 00 \mathrm{~h}$ ) with commercial salmon feed (Tess Nutra G, $3.0 \mathrm{~mm}$ : $47.6 \%$ protein, $21.1 \%$ lipid, $8.8 \%$ water and energy content $21.1 \mathrm{~kJ} \mathrm{~g}^{-1}$ ) and kept under a photoperiod of $16 \mathrm{~h}$ light and $8 \mathrm{~h}$ dark. Then, $52 \mathrm{~d}$ p.v., the tank water temperatures were increased over a period of $8 \mathrm{~h}$ to either 14.1 or $18.1^{\circ} \mathrm{C}$, or were kept at $10.3^{\circ} \mathrm{C}$ (3 replicates per temperature: Fig. 1). Fish were maintained at these controlled $\left( \pm 0.5^{\circ} \mathrm{C} \mathrm{d}^{-1}\right)$ temperatures for $7 \mathrm{wk}$.

Plasma samples and handling of fish. Fish were sampled before the temperature manipulation (Day 49 p.v.), and afterwards (Days 75 and 103 p.v.) (Fig. 1); 7 individuals were also sampled in April, before the vaccinations. The fish were collected, killed with a blow to the head, and sampled randomly. They were anaesthetized by immersion in MS-222. Blood was drawn from the dorsal vein into a heparinized syringe and immediately centrifuged. Plasma was then aliquoted and immediately frozen in liquid nitrogen. The samples were later stored at $-80^{\circ} \mathrm{C}$.

Measurements. The specific antibody response towards aAS (but not tAS) was analyzed because the amount of plasma was limited and the response towards aAS was considered more important. Anti-aAS-specific antibodies were analyzed with a double-sandwich enzyme-linked immunosorbent assay (ds-ELISA) with $1 \%(\mathrm{w} / \mathrm{v})$ bovine serum albumin (BSA) in phosphatebuffered saline (PBS) as the blocking solution (Thuvander et al. 1987, Magnaðottir \& Gudmundsðottir 1992) in wells precoated with poly-L-lysine (Graves 1988). Microplates were coated with $10^{-5} \mathrm{cfu} \mathrm{ml}^{-1}$ of sonicated aAS cells (Sorensen \& Brodbeck 1986, Kuen et al. 1993). Bacteria cells were sonicated for 8 min per tube at an amplitude of 6 to 7 : 30 s sonication followed by 30 s rest per tube. For the ds-ELISA assay, anti-charr IgM-rabbit polyclonal antibodies were produced, since in preliminary tests antibodies against Atlantic salmon and rainbow trout immunoglobulins did not cross-react with charr immunoglobulin. The secondary antibody was anti-rabbit IgG peroxidase conjugate (SIGMA, A-9169). Optical density was read at $492 \mathrm{~nm}$ (optical density,

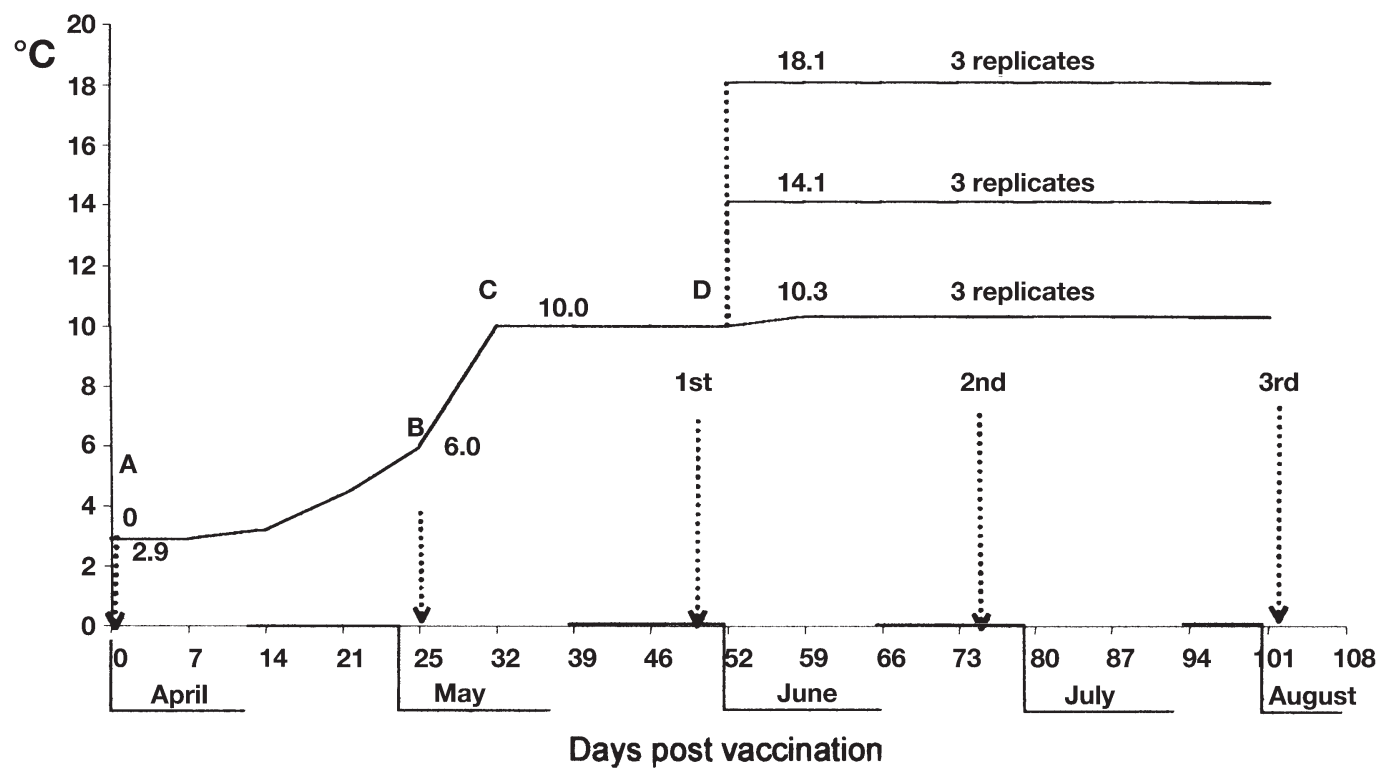

Fig. 1. Schematic diagram of experimental design: 1 yr old Arctic charr Salvelinus alpinus were (A) intraperitoneally vaccinated in April at $2.9^{\circ} \mathrm{C}$ and (B) individually tagged. They were kept at ambient water temperature for $25 \mathrm{~d}$ with temperature increasing from 2.9 to $6.0^{\circ} \mathrm{C}(\mathrm{A}, \mathrm{B})$. From Day 25 to Day 32, the water temperature was raised to $10^{\circ} \mathrm{C}(\mathrm{B}, \mathrm{C})$. Unvaccinated and vaccinated charr were randomly placed into 3 temperature treatment groups: 72 vaccinated and 31 control fish per 2501 tank; 3 replicates at each temperature; total of 9 tanks $(\mathrm{C})$ and kept at $10^{\circ} \mathrm{C}$ for $20 \mathrm{~d}(\mathrm{C}, \mathrm{D})$. The treatment groups were exposed to the relevant test temperatures within $8 \mathrm{~h}$ (D). Temperature change in the test groups was $\pm 0.5^{\circ} \mathrm{C} \mathrm{d}^{-1}$. Blood samples were collected once in April prior to vaccination (0), and subsequently in June, July and August (1st, 2nd, and 3rd respectively) 
$\mathrm{OD}_{492}$ ) with a plate reader (Labsystems Multiskan ${ }^{\circledR}$ $\mathrm{MCC} / 340)$.

Lysozyme activity in plasma was determined by a turbidometric assay (Parry et al. 1965). Micrococcus lysodeikticus (Sigma Incwere)-lyophilised cells (30 mg suspended in $100 \mathrm{ml}$ of sodium phosphate buffer, $0.1 \mathrm{M}$ $\mathrm{Na}_{2} \mathrm{HPO}_{4} / \mathrm{NaH}_{2} \mathrm{PO}, \mathrm{pH} 6.2$ ), $150 \mu \mathrm{l}$ of micrococci suspension and $10 \mu \mathrm{l}$ of undiluted plasma were applied to 96-microtitre plates on ice, in 3 replicates. The decline in absorbance at $550 \mathrm{~nm}$ was measured over $5 \mathrm{~min}$ at 1 min intervals immediately after addition of the bacterial suspension (Multiskan ${ }^{\circledR}$ MCC/340, Labsystems). One unit of lysozyme activity was expressed as the amount of lysozyme that caused a decrease in absorbance of $0.001 \mathrm{~min}^{-1}$ (Lie et al. 1989).

The activity of the complement system via the classical pathway was measured using sensitized, sheep, red blood-cells (SRBC) as a substrate (Reid \& Porter 1981, Joiner et al. 1984, Yano 1992). Antibodies against SRBC were produced by injecting (i.p.) charr (average weight $1 \mathrm{~kg}$ ) with $0.2 \mathrm{ml}$ of a $5 \%$ solution of washed SRBC in PBS (pH 7.2). After 8 wk, the fish received a booster injection with a similar solution and were then euthanised $14 \mathrm{~d}$ later. Blood was drawn from the caudal vein and allowed to clot at room temperature. The serum was obtained by centrifugation, aliquoted and stored at $-80^{\circ} \mathrm{C}$. To determine the correct dilution for sensitization of SRBC, antiserum was diluted from $1 / 100$ to $1 / 3200$ in gelatin veronal buffer (GVB). The dilution was then incubated with SRBC suspension $\left(10^{9}\right.$ cells ml $\left.{ }^{-1}\right)$ for $20 \mathrm{~min}$ at $25^{\circ} \mathrm{C}$. An appropriate dilution of unheated charr serum was added and the tubes were incubated for $60 \mathrm{~min}$ at $25^{\circ} \mathrm{C}$ and centrifuged; absorbance was measured at $541 \mathrm{~nm}$. The percentage of haemolysis obtained was then plotted against the dilutions of anti-SRBC serum to identify a point at which haemolysis reached a plateau. Optimal sensitization was obtained with an anti-SRBC serum dilution of $1 / 400$. The complement system, the classical pathway for charr, was inactivated at $42^{\circ} \mathrm{C}$ for $20 \mathrm{~min}$ and then diluted 1:400 in EDTA-GVB, pH 7.4. Equal volumes of SRBC suspension $\left(10^{9}\right.$ cells $\left.\mathrm{ml}^{-1}\right)$ and serum were incubated at $25^{\circ} \mathrm{C}$ for $30 \mathrm{~min}$. The sensitized cells were washed in GVB and adjusted to $5 \times 10^{8} \mathrm{cells} \mathrm{ml}^{-1}$.

To measure haemolytic activity, $20 \mathrm{ml}$ of pre-sensitized SRBC were mixed with $80 \mathrm{ml}$ of the diluted EDTA-GVB containing $10 \%$ of plasma. After incubation at $25^{\circ} \mathrm{C}$ for $60 \mathrm{~min}$, the unhaemolysed cells were pelleted by centrifugation for $10 \mathrm{~min}$ and haemolysed with $150 \mathrm{ml}$ of $\mathrm{H}_{2} \mathrm{O}$ (Pelkonen \& Pluschke 1989). Absorbance was read at $540 \mathrm{~nm}$. Control wells contained distilled water for $100 \%$ haemolysis and buffer solution for $0 \%$ haemolysis. Haemolysis was calculated as $100 \% \times$ (Observed absorbance at $540 \mathrm{~nm}\left[\mathrm{Abs}_{540 \mathrm{~nm}} \mathrm{Obs}\right] /$ absorbance of buffer at $540 \mathrm{~nm}$ [ $\operatorname{Abs}_{540 \mathrm{~nm}}$ buffer] $)=$ the percentage of haemolysis caused by the classical pathway of the complement system.

Activity of the alternative complement pathway was studied by direct haemolysis of rabbit red blood cells (RaRBC) as described by Yano (1992). Washed RaRBC $2 \times 10^{8}$ cells ml ${ }^{-1}$ in EGTA-Mg ${ }^{2+}-$ GVB, at $\mathrm{pH} 7.5$, were incubated with charr serum diluted to $1 / 10$ for $90 \mathrm{~min}$ at $25^{\circ} \mathrm{C}$ with mild shaking on an end-to-end shaker. The unhaemolysed cells were pelleted by centrifugation. Haemolytic activity was measured after lysing the cells with $\mathrm{H}_{2} \mathrm{O}\left(175 \mu \mathrm{l}\right.$ well $\left.^{-1}\right)$. Absorbance was read at $414 \mathrm{~nm}$, and the percentage of haemolysis caused by the alternative pathway of the complement system was calculated as $100 \% \times\left(\mathrm{Abs}_{414 \mathrm{~nm}} \mathrm{Obs}_{\mathrm{Ab}} \mathrm{Abs}_{414 \mathrm{~nm}}\right.$ buffer $)$.

The total plasma protein concentration was measured using a protein assay with BSA as a standard (Bradford 1976).

Statistical analyses. None of the data, except the aAS-specific antibody level and the total plasma protein concentration, were normally distributed. For simplicity in statistical analysis, the distribution-free procedure was used. Variables were rank-transformed and full factorial 3-way analysis of variance was then performed to analyze the effects of temperature, vaccination and sampling time after the temperature manipulation (Conover \& Iman 1981). Statistically significant influence was considered to exist if $p<0.05$.

\section{RESULTS}

\section{Immune functions of unvaccinated charr}

The anti-aAS-specific antibody level of unvaccinated Arctic charr was lower in April before vaccination than later in the summer (Fig. 2), when specific activity towards aAS cells increased in all temperature groups $\left(10.3,14.1\right.$ and $\left.18.1^{\circ} \mathrm{C}\right)$. The $\mathrm{OD}_{492 \mathrm{~nm}}$ reading was higher than that of the background value (OD 0.03) (Fig. 2). The anti-aAS-specific antibody level was not analyzed in the $10.3^{\circ} \mathrm{C}$ temperature group in August due to an insufficient amount of plasma for the analyses (Fig. 2).

Plasma lysozyme activity was higher in April (126 U $\mathrm{ml}^{-1}$ ) than in the summer $\left(95 \mathrm{U} \mathrm{ml}^{-1}\right)$ among unvaccinated charr (Fig. 3). In August, only the group of unvaccinated charr kept at $18.1^{\circ} \mathrm{C}$ exhibited higher lysozyme activity $\left(200 \mathrm{U} \mathrm{ml}^{-1}\right)$ than unvaccinated charr in April (Fig. 3).

The haemolytic activity of the classical and alternative pathways of the complement system was low before vaccination in April (4.5 and 1.5\% respectively), but increased later in the summer (Fig. 4). The complement system via the classical pathway reached $50 \%$ haemolysis in August (Fig. 4a), while the alternative complement pathway of unvaccinated charr displayed the high- 

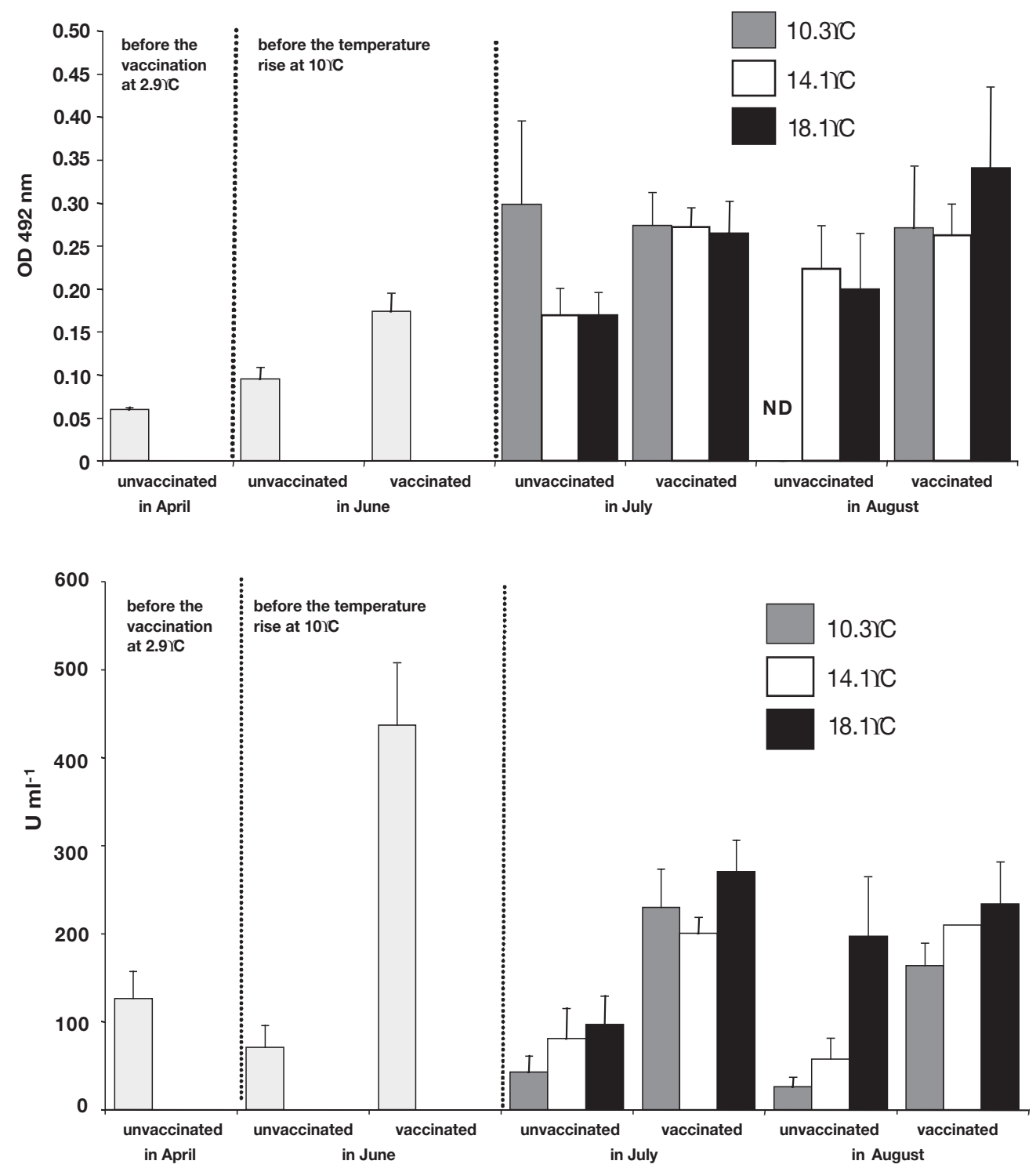

Fig. 2. Salvelinus alpinus. Atypical Aeromonas salmonicida-specific antibodies in unvaccinated and vaccinated Arctic charr prior to vaccination $(\mathrm{n}=7)$ in April, and in unvaccinated $(\mathrm{n}=29)$ and vaccinated $(\mathrm{n}=48)$ charr in June (49 d post-vaccination (p.v.): $25 \mathrm{~d}$ at temperatures increasing from 2.9 to $6.0^{\circ} \mathrm{C} ; 7 \mathrm{~d}$ at temperatures increasing from 6.0 to $10.0^{\circ} \mathrm{C}$, and 17 $\mathrm{d}$ at $10^{\circ} \mathrm{C}$ ). Number of unvaccinated and vaccinated charr sampled in July after establishing the temperatures groups at 10.3, 14.1 and $18.1^{\circ} \mathrm{C}$ were 29 and 58 respectively, $75 \mathrm{~d}$ p.v.; and in $\mathrm{Au}-$ gust 18 and 44 respectively, $103 \mathrm{~d}$ p.v. ND: not detected. OD: optical density. Bars show SEM

Fig. 3. Salvelinus alpinus. Lysozyme activity $\left(\mathrm{U} \mathrm{ml}^{-1}\right)$ in plasma of Arctic charr, prior to vaccination $(\mathrm{n}=6)$ and in unvaccinated ( $\mathrm{n}=29)$ and vaccinated $(\mathrm{n}=48)$ charr in June ( $49 \mathrm{~d}$ post vaccination (p.v.): $25 \mathrm{~d}$ at temperatures increasing from 2.9 to $6.0^{\circ} \mathrm{C}$; for $7 \mathrm{~d}$ at temperatures increasing from 6.0 to $10.0^{\circ} \mathrm{C}$ and $17 \mathrm{~d}$ at $10^{\circ} \mathrm{C}$. Number of unvaccinated and vaccinated charr sampled in July after establishing the temperatures groups at 10.3, 14.1 and $18.1^{\circ} \mathrm{C}$ were 38 and 88 respectively, $75 \mathrm{~d}$ p.v.; and in August 50 and 94 respectively, 103 d p.v. Bars show SEM

est activity in June (over $50 \%$ haemolysis) and a lower haemolytic activity (10\%) in July and August (Fig. 4b).

Some individuals exhibited no lysozyme activity or haemolytic activity of the complement system at all, or the activity was below the detection limit of the methods. This was also reflected in the high coefficient of variation, CV (Table 1).

The total plasma protein concentration of unvaccinated charr increased from about $40 \mathrm{mg} \mathrm{ml}^{-1}$ in April to about $70 \mathrm{mg} \mathrm{ml}^{-1}$ in July/August (data not shown).

\section{Effect of vaccination, temperature and sampling time on immune functions}

The anti-aAS-specific antibody response was significantly $(p<0.00)$ stronger in vaccinated than in unvac- cinated charr at all p.v. temperatures (Fig. 2, Table 2). Sampling time had a slight effect $(p<0.05)$ with specific antibody response in vaccinated charr increasing from June to August (Fig. 2, Table 2).

At all p.v. temperatures, plasma lysozyme activity in June, July and August significantly increased ( $p<0.00)$ in vaccinated charr (Fig. 3, Table 2). Lysozyme activity was also slightly $(\mathrm{p}<0.05)$ influenced by temperature (Fig. 3, Table 2), being greater at $10.0,10.3^{\circ} \mathrm{C}$ and 14.1 ${ }^{\circ} \mathrm{C}$ than at $18.1^{\circ} \mathrm{C}$ (Fig. 3, Table 2 ). The highest plasma lysozyme activity in vaccinated charr $\left(490 \mathrm{U} \mathrm{ml}^{-1}\right)$ was reached in June $49 \mathrm{~d}$ p.v.; thereafter the activity declined (Fig. 3). The activity at $10.3^{\circ} \mathrm{C}$ in August, 103 d p.v., was $<200 \mathrm{U} \mathrm{ml}^{-1}$ (Fig. 3).

The haemolytic activity of both the classical and alternative pathways of the complement system was significantly $(p<0.00)$ affected by the time of sampling, but not 
by vaccination or water temperature (Fig. 4, Table 2). The haemolytic activity of the classical complement pathway was greatest in August (Fig. 4a), while the alternative pathway was most active in both unvaccinated and vaccinated charr in June (Fig. 4b).

Total plasma protein concentration was significantly increased by vaccination (Table 2).

\section{DISCUSSION}

The main factors indicating the activation of both the non-specific and specific immune responses of charr
Table 1. Salvelinus alpinus. Immune parameters and total plasma protein concentration of unvaccinated Arctic charr in June at $10.0^{\circ} \mathrm{C}$. aAs-specific antibodies: atypical Aeromonas salmonicida-specific antibodies

\begin{tabular}{|lcccrr|}
\hline & $\begin{array}{c}\text { aAs- } \\
\text { specific } \\
\text { antibodies } \\
(\text { OD } 429 \mathrm{~nm})\end{array}$ & $\begin{array}{c}\text { Lysozyme } \\
\text { activity }\end{array}$ & $\begin{array}{c}\text { Complement activity } \\
\text { Classical }\end{array}$ & $\begin{array}{c}\text { Alternative } \\
\text { Plasma } \\
\text { protein } \\
\text { conc. } \\
\left(\mathrm{Ug} \mathrm{ml}^{-1}\right)\end{array}$ \\
\hline Minimum & 0.06 & 0.00 & 0.00 & 0.00 & 19.83 \\
Maximum & 0.21 & 330.00 & 81.03 & 89.24 & 104.00 \\
Median & 0.09 & 40.00 & 16.00 & 22.89 & 57.44 \\
Mean & 0.10 & 82.76 & 27.24 & 36.15 & 61.89 \\
SD & 0.01 & 18.51 & 5.70 & 9.77 & 3.94 \\
CV & 0.38 & 1.20 & 1.13 & 1.05 & 0.34 \\
Skewness & 0.43 & 0.43 & 0.43 & 0.58 & 0.43 \\
Kurtosis & 3.22 & 0.06 & -1.15 & -1.56 & -0.41 \\
No. fish & 29 & 29 & 29 & 15 & 29 \\
\hline
\end{tabular}
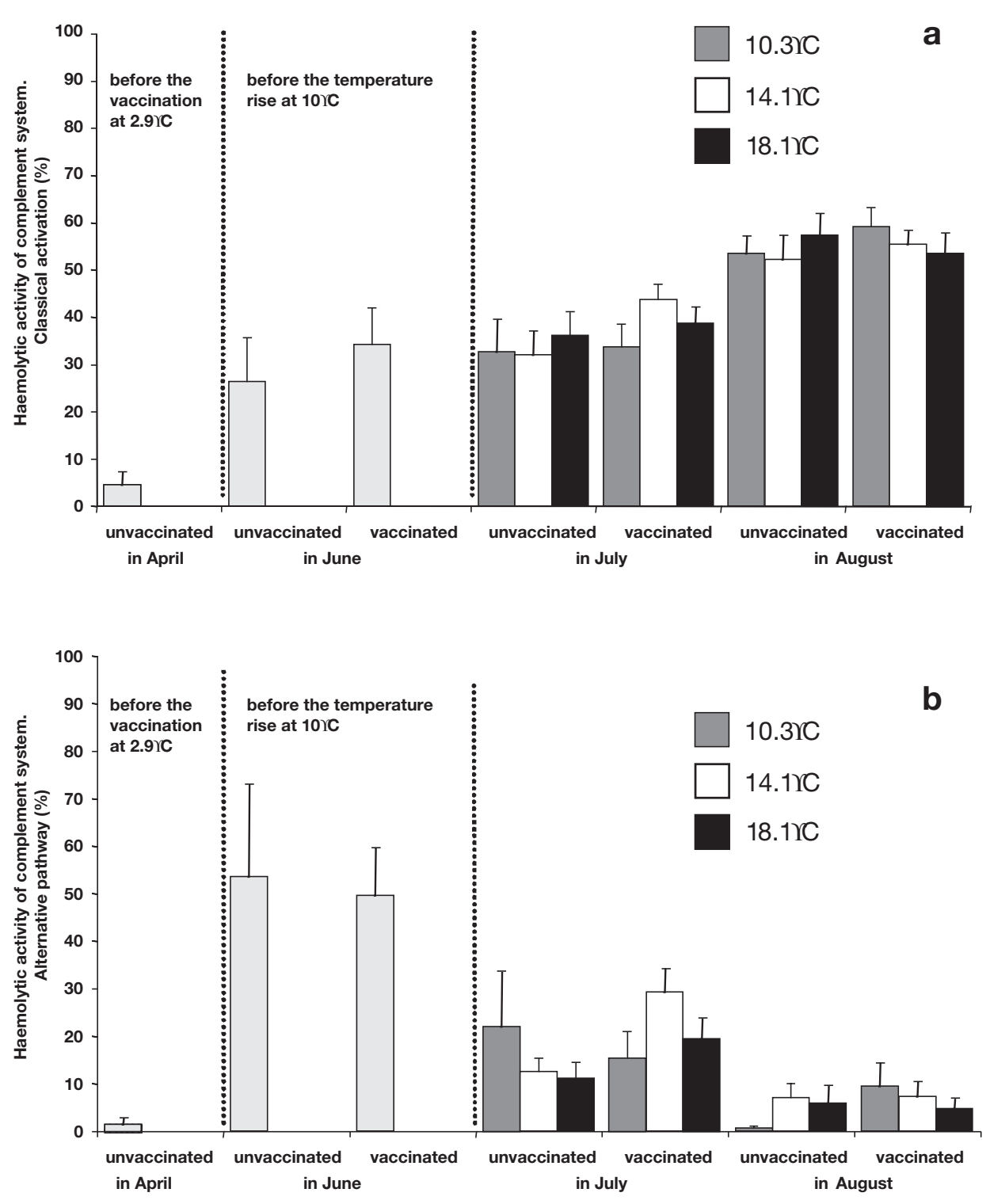

Fig. 4. Salvelinus alpinus. Haemolytic activity (\%) of (a) classical pathway and (b) alternative pathway of complement system of unvaccinated and vaccinated Arctic charr prior to vaccination ( $\mathrm{n}=7$ for classical and 6 for alternative pathway); and of unvaccinated $(\mathrm{n}=29$ for classical and 15 for alternative pathway) and vaccinated ( $\mathrm{n}=48$ for classical and 17 for alternative pathway) charr in June (49 d post-vaccination (p.v.): $25 \mathrm{~d}$ at temperatures increasing from 2.9 to $6.0^{\circ} \mathrm{C} ; 7 \mathrm{~d}$ at temperatures increasing from 6.0 to $10.0^{\circ} \mathrm{C}$, and $17 \mathrm{~d}$ at $10^{\circ} \mathrm{C}$ ). Number of unvaccinated and vaccinated charr sampled in July after establishing the temperatures groups at $10.3,14.1$ and $18.1^{\circ} \mathrm{C}$ ( $\mathrm{n}=50$ for classical 49 for alternative pathway; and 113 for classical and 113 for alternative pathway; $75 \mathrm{~d}$ p.v.) and in August ( $\mathrm{n}=43$ for classical and 43 for alternative pathway; and $\mathrm{n}=82$ for classical and 82 for alternative; $103 \mathrm{~d}$ p.v.). Bars show SEM 
Table 2. Salvelinus alpinus. Influence of vaccination, temperature and time of sampling, and their interactions on immune functions and total plasma protein concentration of unvaccinated and vaccinated Arctic charr. Statistical analyses of 3-way ANOVA of rank-transformed data; $\mathrm{p}<0.05=$ significant differences; $\mathrm{p}>0.05=$ non significant difference

\begin{tabular}{|lcccccc|}
\hline Factor & $\begin{array}{c}\text { aAs- } \\
\text { specific } \\
\text { antibodies } \\
\mathrm{p}\end{array}$ & $\begin{array}{c}\text { Lysozyme } \\
\text { activity }\end{array}$ & $\mathrm{p}$ & $\mathrm{c}$ & $\begin{array}{c}\text { Complement activity } \\
\text { Classical }\end{array}$ & $\begin{array}{c}\text { Total } \\
\text { plasma } \\
\text { protein } \\
\mathrm{p}\end{array}$ \\
\hline Vaccination (Vacc.) & 0.0065 & 0.0000 & 0.0973 & 0.4697 & 0.0000 \\
Temperature (Temp). & 0.5465 & 0.0105 & 0.7010 & 0.1973 & 0.2271 \\
Time of sampling (T.S.) & 0.0456 & 0.8617 & 0.0000 & 0.0000 & 0.6104 \\
Vacc. $\times$ Temp. & 0.5400 & 0.6641 & 0.6111 & 0.9908 & 0.1022 \\
Vacc. $\times$ T.S. & 0.5400 & 0.2669 & 0.4370 & 0.9448 & 0.2862 \\
Temp. $\times$ T.S. & 0.9644 & 0.5538 & 0.4901 & 0.8404 & 0.8188 \\
Vacc. $\times$ Temp. $\times$ T.S. & 0.0549 & 0.0822 & 0.4297 & 0.2479 & 0.9167 \\
No unvacc. fish & 47 & 88 & 93 & 92 & 92 \\
No vacc. fish & 100 & 178 & 191 & 191 & 186 \\
\hline
\end{tabular}

The classical pathway of the complement system was activated in the course of the experiment regardless of the vaccination status. Surprisingly, vaccination did not stimulate the haemolytic activity of either the classical or alternative pathways of the complement system in this study. Engstad et al. (1992) demonstrated an increase in spontaneous haemolytic activity in Atlantic salmon after active immunization. The inconsistency between the present study and that of Engstad et al. may be a result of differences in the activation of the complement system between salmonid species.

Interestingly, the plasma lysozyme activity and the haemolytic activity of the complement system via the alter-

after bivalent aAS- and tAS-vaccination are the significant increase in plasma lysozyme activity and the appearance of anti-aAS-specific antibodies in Arctic charr.

The increase in the plasma lysozyme activity in vaccinated charr indicates the activation of the nonspecific immune defense functions (see e.g. Roitt 1994, Janeway et al. 1999). This was also shown by Engstad et al. (1992) in Atlantic salmon after injection of M-glycan. The production of specific antibodies against formalin-inactivated Aeromonas salmonicida salmonicida bacteria has also been reported by Rainger \& Rowley (1993) and O'Dowd et al. (1999).

In the present study, the anti-aAS-specific antibody response increased from June to August in both unvaccinated and vaccinated charr. Rintamäki \& Valtonen (1991) have reported aAS outbreaks in Finland to occur at water temperatures higher than $15^{\circ} \mathrm{C}$, which indicates an increase in the number of aAS or related Aeromonas bacteria in incoming water in July and August. However, low $\mathrm{OD}_{492 \mathrm{~nm}}$ readings reflected a weak recognition of epitopes of aAS bacteria, which indicates that killed aAS cells in the vaccine were not strongly immunogenic. The specificity of the recognition of sonicated aAS cells on ds-ELISA plates by charr plasma is unknown. Plasma antibodies against other Aeromonas spp. in the environment might also interfere with the assay.

The role of the specific antibody level in host protection is currently under debate. Elevated antibody levels after vaccination have not been shown to correlate with protective immunity in all cases (Thuvander et al. 1993). The specific antibody level in Atlantic salmon has been reported to increase after either experimental or natural exposure to Aeromonas salmonicida achromogenes (Magnaðottir et al. 1995). native pathway peaked in June. In the early summer the fish might require an effective non-specific defense mechanism (simultaneous increase in lysozyme and alternative pathway of complement system activity) against microbes (pathogens) present in the large influx of melt water after winter (RintamäkiKinnunen 1997).

In our study, the production of anti-aAS-specific antibodies by vaccinated charr was paralleled by an increased concentration of total plasma proteins at all test temperatures. Hrubec et al. (1997) also reported that the total serum protein concentration of hybrid stripped bass was not significantly influenced by temperature. There have been discrepancies between results in the literature concerning the simultaneous changes in serum IgM level and the total protein concentration. Total protein level and IgM level have been reported to increase in Atlantic salmon during aAS infection (Magnaðottir \& Gudmundsðottir 1992, Magnaðottir et al. 1995). However, there was no significant correlation between the serum protein concentration and IgM level after Vibrio anguillarum infection (Coeurdacier et al. 1997).

Charr were vaccinated at $2.9^{\circ} \mathrm{C}$, which has been shown to be a sufficiently high vaccination temperature to induce protection against Vibrio salmonicida (Lillehaug et al. 1993). Atlantic salmon vaccinated at 2, 4 and $6^{\circ} \mathrm{C}$ against $V$. salmonicida showed better protection than fish vaccinated at 8 or $10^{\circ} \mathrm{C}$, although the mean antibody levels were lower in the low-temperature groups (Lillehaug et al. 1993). This is also supported by the present results; a statistically significant increase in antibody level was recorded as a function of vaccination and of sampling time, but not as a function of temperature. There was no difference in the production of antibodies between the 3 temperature 
groups $\left(10,14\right.$ and $\left.18^{\circ} \mathrm{C}\right)$. The differences among individual fish are reflected in the large standard error for the unvaccinated charr data at $10.3^{\circ} \mathrm{C}$ and in the vaccinated charr data at $18.1^{\circ} \mathrm{C}$. Thus, no statistically significant difference was obtained between temperatures in the analyses.

The immune defense system of Arctic charr can be stimulated by bivalent aAS- and tAS-vaccination. There is no need to keep charr at high temperatures after vaccination (to boost the vaccination); they can be held at their optimum temperatures for growth which, for the farmed Lake Inari Arctic charr, range from 13 to $14^{\circ} \mathrm{C}$ (Swift 1964, Jobling et al. 1993, Lyytikäinen 1998).

Acknowledgements. This study was funded by the Nordic Council of Ministers under the project number 6608 0400. We are also grateful to the staff at Finnish Game and Fisheries Research Institute, Laukaa Fisheries Research and Aquaculture, for maintenance of our experimental fish and excellent aquaculture facilities. Our warmest thanks to Dr Christian Syvertsen and Dr Ilmari Jokinen for their valuable comments on the text.

\section{LITERATURE CITED}

Bradford MM (1976) A rapid and sensitive method for the quantitation of microgram quantities of protein utilizing the principle of protein-dye binding. Anal Biochem 72: 248-254

Coeurdacier JL, Pepin JF, Fauvel C, Legall P, Bourmaud AF, Romenstand B (1997) Alterations in total protein, IgM and specific antibody activity of male and female sea bass (Dicentrarchus labrax L., 1758) sera following injection with killed Vibrio anguillarum. Fish Shellfish Immunol 7: 151-160

Conover WJ, Iman RL (1981) Rank transformation as a bridge between parametric and nonparametric statistics. Am Statistn 35:124-129

Engstad RE, Robertsen B, Frivold E (1992) Yeast glucan induces increase in lysozyme and complement mediated haemolytic activity in Atlantic salmon blood. Fish Shellfish Immunol 2:287-297

Garrote A, Bonet R., Merino S, Simon-Pujol MD, Congregado F (1992) Occurrence of capsule in A. salmonicida. FEMS Microbiol Lett 95:127-132

Graves HCB (1988) The effect of surface charge on non-specific binding of rabbitimmunoglobulin $\mathrm{G}$ in solid-phase immunoassay. J Immunol Meth 111:157-166

Gudmundsðottir BK (1997) Aeromonas salmonicida subsp. achromogenes - a study of extracellular virulence factors and immunity in Atlantic salmon (Salmo salar L.). PhD thesis, University of Iceland, Keldur

Gudmundsðottir BK,Magnadðottir B (1997) Protection of Atlantic salmon (Salmo salar L.) against an experimental infection of Aeromonas salmonicida subsp. achromogenes. Fish Shellfish Immunol 7:55-69

Gudmundsðottir BK, Hastings TS, Ellis AE (1990) Isolation of a new toxic protease from a strain of Aeromonas salmonicida subspecies achromogenes. Dis Aquat Org 9:199-208

Hrubec TC, Robertson JL, Smith SA (1997) Effects of temperature on hematologic and serum biochemical profiles of hybrid striped bass (Morone chrysops $\times$ Morone saxatilis). Am J Vet Res 58:126-130
Janeway CA, Travers P, Walport M, Capra JD (eds) (1999) Immunobiology - the immune system in health and disease, 4th edn. Elsevier Science, New York

Jobling M, Jørgensen EH, Arnesen AM, Ringø E (1993) Feeding, growth and environmental requirements of arctic char: a review of aquaculture potential. Aquac Int 1:20-46

Johnson L (1980) The Arctic charr (Salvelinus alpinus). In: Balon EK (ed) Charrs, salmonid fishes of genus salvelinus. Dr W. Junk Publishers, The Hague, p 15-98

Joiner KA, Brown EJ, Frank MM (1984) Complement and bacteria: chemistry and biology in host defense. Annu Rev Immunol 84:461-491

Kuen SK, Ming CH, Yap SF (1993) Background noise in ELISA procedures. Influence of the $\mathrm{pH}$ of the coating buffer and correlations with serum IgM concentration. J Immunol Methods 163:277-278

Lie Ø, Evensen Ø, Sørensen A, Frøysadal E (1989) Study on lysozyme activity in some fish species. Dis Aquat Org 6: $1-5$

Lillehaug A, Ramstad A, Bækken K, Reitan LJ, (1993) Protective immunity of Atlantic salmon (Salmo salar L.) vaccinated at different water temperatures. Fish Shellfish Immunol 3:143-156

Lyytikäinen T (1998) Thermal biology of underyearling Lake Inari Arctic charr Salvelinus alpinus. University of Jyväskylä, Jyväskylä (Biological Research Reports Univ Jyväskylä)

Magnaðottir B, Gudmundsðottir BK (1992) A comparison of total and specific immunoglobulin levels in healthy Atlantic salmon (Salmo salar L.) and in salmon naturally infected with Aeromonas salmonicida spp. achromogenes. Vet Immunol Immunopathol 32:179-189

Magnaðottir B, Gudmundsðottir S, Gudmundsðottir BK (1995) Study of the humoral response of Atlantic salmon (Salmo salar L.), naturally infected with Aeromonas salmonicida ssp. achromogenes. Vet Immunol Immunopathol 49: 127-142

Merino S, Albert S, Tomas JM (1994) Aeromonas salmonicida resistance to complement-mediated killing. Infect Immun 62:5483-5490

Midtlyng PJ, Reitan LJ, Speilberg (1996) Experimental studies on the efficacy and side-effects of intraperitoneal vaccination of Atlantic salmon (Salmo salar L.) against furunculosis. Fish Shellfish Immunol 6:335-350

Møyner K (1993) Changes in serum protein composition occur in Atlantic salmon, Salmo salar L., during Aeromonas salmonicida infection. J Fish Dis 16:601-604

O'Dowd AM, Brincknell IR, Secombes CJ Ellis AE (1999) The primary and secondary antibody responses to IROMP antigens in Atlantic salmon (Salmo salar L.) immunised with $\mathrm{A}^{+}$and $\mathrm{A}^{-}$Aeromonas salmonicida bacterins. Fish Shellfish Immunol 9:121-138

Parry RM, Chandan Jr RC Shahani KM(1965) A rapid and sensitive assay of muramidase. Proc Soc Exp Biol Med 119:384-386

Pelkonen S, Pluschke G (1989) Use of hybridoma immunoglobulin switch variants in the analysis of the protective properties of anti-lipopolysaccaharide antibodies in Eschericia coli K1 infection. Immunology 68:260-264

Pylkkö P, Lyytikäinen T, Ritola O, Pelkonen S (2000) Vaccination influences growth of Arctic charr. Dis Aquat Org 43: $77-80$

Rainger GE Rowley AF (1993) Antibacterial activity in the serum and mucus of rainbow trout, Oncorhynchus mykiss, following immunisation with Aeromonas salmonicida. Fish Shellfish Immunol 3:475-482

Reid BM, Porter RR (1981) The proteolytic activation systems 
of complement. Ann Rev Biochem 50:433-464

Rintamäki P, Valtonen T (1991) Aeromonas salmonicida in Finland: pathological problems associated with atypical and typical strains. J Fish Dis 14:323-331

Rintamäki-Kinnunen P (1997) Parasitic and bacterial diseases at salmonid fish farms in northern Finland. PhD thesis, University of Oulu, Oulu

Roitt I (1994) Essential immunology, 8th edn. Blackwell Science, Paris

Sorensen K, Brodbeck U (1986) Assessment of coating-efficiency in ELISA plates by direct protein determination. J Immunol Meth 95:291-293

Swift DR(1964) The effect of temperature and oxygen on the

Editorial responsibility: David Bruno,

Aberdeen, Scotland, UK growth rate of the Windemere char Salvelinus alpinus willughbii. Comp Biochem Physiol 12:179-183

Thuvander A, Hongslo T, Janson J, Sundquist B (1987) Duration of protective immunity and antibody titres measured by ELISA after vaccination of rainbow trout, Salmo gairdneri Richardson, against vibriosis. J Fish Dis 10:479-486

Thuvander A, Wichard UP, Reitan LJ (1993) Humoral antibody response of brown trout Salmo trutta vaccinated against furunculosis. Dis Aquat Org 17:17-23

Yano T (1992) Assays of hemolytic complement activity. In: Stolen JS, Fletchen TC, Anderson DP, Kaattari SL, Rowley AS (eds) Tech fish immunol-technical communications. New Jersey, p 131-141

Submitted: July 19, 2001; Accepted: April 12, 2002 Proofs received from author(s): September 26, 2002 